\title{
Türkçe Öğretmeni Adaylarının Yaşam Becerileri ile İlgili Görüşlerinin Çeşitli Değişkenler Açısından İncelenmesi ${ }^{1}$
}

\author{
Mete Yusuf USTABULUT \\ Dr. Öğr. Üyesi, Bayburt Üniversitesi, \\ Eğitim Fakültesi, Türkçe Eğitimi Ana Bilim Dalı \\ meteustabulut@bayburt.edu.tr \\ Orcid ID: https://orcid.org/0000-0002-8864-645X
}

\section{Öz}

$\mathrm{Bu}$ araştırmanın amacı Türkçe öğretmeni adaylarının yaşam becerileri ile ilgili görüşlerini çeşitli değişkenler açısından incelemektir. Araştırma nicel araştırma modellerinden ilişkisel tarama modeli kullanılmıştır. Araştırmanın örneklemini basit seçkisiz yolla seçilen 216 Türkçe öğretmeni adayı oluşturmaktadır. Araştırma verileri toplamak amacıyla yaşam becerileri ölçeği kullanılmıştır. Araştırmanın verilerini analiz etmek amacıyla betimsel analiz, t-testi, ANOVA, koelasyon analizi testleri kullanılmıştır. Türkçe öğretmeni adayları, duygularla ve stresle başa çıkma konusunda kararsız olduklarını; empati kurma, özfarkındalık, karar verme, problem çözme, yaratıcı düşünme, eleştirel düşünce, iletişim, kişilerarası ilişki becerileri konusunda kendilerini yeterli gördüklerini belirtmektedirler. Türkçe öğretmeni adaylarının yaşam beceri ile ilgili görüşleriyle cinsiyetleri arasında anlamlı bir ilişki vardır. Türkçe öğretmeni adaylarının yaşam beceriyle ilgili görüşleriyle not ortalamaları, yaşları ve sınıf düzeyleri arasında anlamlı bir ilişki vardır. Türkçe öğretmeni adaylarının yaşam beceri ile ilgili görüşleriyle internette geçirdikleri süre arasında anlamlı bir ilişki yoktur.

Anahtar Kelimeler: Beceri, Türkçe Öğretmeni Adayları, Yaşam Becerileri.

\section{Examining the Opinions of Turkish Teacher Candidates on Life Skills in Terms of Various Variables}

\begin{abstract}
The aim of this study is to examine the views of Turkish teacher candidates about life skills in terms of various variables. The relational survey model, one of

${ }^{1}$ Makale Geliş/Kabul Tarihi: 17.02.2020 / 14.04.2020

Künye Bilgisi: Ustabulut, M. Y. (2021). Türkçe öğretmeni adaylarının yaşam becerileri ile ilgili görüşlerinin çeşitli değişkenler açısından incelenmesi. Kahramanmaraş Sütçü Imam Üniversitesi Sosyal Bilimler Dergisi, 18(1), 205-219. DOI: 10.33437/ksusbd.879817
\end{abstract}


the quantitative research models, was used. The sample of the study consists of 216 Turkish teacher candidates selected by simple random method. Life skills scale was used to collect research data. Descriptive analysis, t-test, ANOVA, coelation analysis tests were used to analyze the data of the research. Turkish teacher candidates stated that they were indecisive about coping with emotions and stress; They state that they see themselves competent in empathy, selfawareness, decision making, problem solving, creative thinking, critical thinking, communication and interpersonal relationship skills. There is a significant relationship between the Turkish teacher candidates' views on life skills and their gender. There is a significant relationship between Turkish teacher candidates' views on life skills and their grade point averages, ages and grade levels. There is no significant relationship between Turkish teacher candidates' views on life skills and the time they spend on the internet.

Keywords: Skill, Turkish Teacher Candidates, Life Skills.

\section{GİRIŞ}

20. yüzyılın sanayi çağından 21. yüzyıl bilgi çağına geçerken, eğitimde beceri temelli bir anlayış hakim olmaktadır. 20. yüzyılda elde edilen başarılar, 21. yüzyılda daha çok çalışmayı gerektirmektedir (Kivunja, 2015). 21. yüzyılda tüm öğrenciler, temel akademik konu bilgilerini; eleştirel düşünme, problem çözme, etkili iletişim gibi günümüz dünyasında başarı için gerekli beceriler ve işbirlikleri bağlamında, öğrenmelidir. Öğrenciler akademik konu bilgisini eleştirel düşünebilen ve etkili bir şekilde iletişim kurabilen, bir temel üzerine inşa etmelidirler (P21, 2009:1 akt. Kivunja, 2015).

Günlük hayatta karşılaşılan zorluklarla başa çıkabilmek için gerekli olan becerilere yaşam becerisi denilmektedir (WHO, 1999: 1). Yaşam becerileri ile ilgili çeşitli sınıflandırmalar bulunsa da en geleneksel sınıflandırma WHO'ya göre yapılan sınıflandırma olup; yaşam becerileri öz farkındalık ve empati, stresle ve duygularla başa çıma, karar verme ve problem çözme, iletişim ve kişilerarası iletişim, yaratıcı ve eleştirel düşünme olmak üzere beşe ayrılır.

"Yaşam becerisi bireyin yaşantısını sürdürebilmesi için gereken becerilerdir. Yaşam becerileriyle bireylerin yaşamlarını kolaylaştırması hedeflenmektedir (Erbil vd.2004 akt. Bahçeci ve Kuru, 2008)." Öğretmenlerin yaşam becerilerini kazanması hem mesleki gelişimleri hem de yapılandırmacı eğitim kapsamında çok önemlidir. Öğretmen eğitiminde de bu becerilerin öğretmen adaylarına kazadırılması gerekmektedir. $\mathrm{Bu}$ becerilerin kazandırılmasının sorumluluğu öğretmendedir (Güleç, 2020)” 
Alanyazında yaşam becerileriyle ilgili yapılan çalışmalar incelendiğinde (Calp, 2020; Deveci, Konuş ve Aydız, 2018; Eskici ve Özsevgeç, 2019; Topcu Bilir, 2019; Ulus, 2018; Ümmet ve Demirci, 2017; Yalçıntaş Sezgin, 2018; Yıldırım ve Temel, 2020; Ursavas ve Karal, 2019) Türkçe öğretmeni adaylarıyla ilgili araştırma yapılmadığı görülmüştür. $\mathrm{Bu}$ araştırmanın amacı Türkçe öğretmeni adaylarının yaşam becerileri ile ilgili görüsslerini çeşitli değişkenler açısından incelemektir.

\section{YÖNTEM}

\section{Araștırmanın Modeli}

Araştırmada Türkçe öğretmeni adaylarının yaşam becerileriyle değişkenler arası ilişki olup olmadığı araştırılmıştır. Bundan dolayı araştırmada ilişkisel tarama modeli kullanılmıştır. Bu modelde iki veya daha fazla değişken arasındaki ilşkiler incelenir (Karasar, 2013). Çalışmada uygulanan anket için Bayburt Üniversitesi Etik Kurulundan 28.12.2020 tarihli 2020/117 karar sayıll etik ilkelere uygun olduğu yönünde etik kurul izni alınmıştır.

\section{Örneklem Grubu}

Araştırmanın örneklem grubunu 216 Türkçe öğretmeni adayı oluşturmaktadır. Araştırmanın örneklemi basit seçkisiz yolla seçilmiştir. $\mathrm{Bu}$ örnekleme yönteminde evreni oluşturan tüm birimlerin eşit seçilme olasılıkları vardır (Karasar, 2013).

Tablo 1. Araştırmanın Örneklem Grubunun Cinsiyetleri

\begin{tabular}{ccc}
\hline Cinsiyet & $\mathrm{f}$ & $\%$ \\
\hline Kadın & 150 & 69.4 \\
Erkek & 66 & 30.6 \\
\hline
\end{tabular}

Tablo 1 incelendiğinde araştırmanın örneklem grubunun \%30.6'sının erkek, \%69.4'ünün kadın olduğu görülmektedir.

Tablo 2. Araştırmaya Katılanların Yaş Grupları

\begin{tabular}{ccc}
\hline Yaş & $\mathrm{f}$ & $\%$ \\
\hline $18-19$ & 25 & 11,6 \\
$20-21$ & 102 & 47,2 \\
$22-23$ & 72 & 33,3 \\
24 ve üzeri & 17 & 7,9 \\
\hline
\end{tabular}


Tablo 2'ye göre araştırmanın örneklem grubunun \%11.6'sının 18-19, \%47.2'sinin 20-21, \%33.3'ünün 22-23, \%7.9'unun 24 ve üzeri yaş aralığında olduğu görülmektedir

Tablo 3. Araştırmanın Örnkelem Grubunun Not Ortalamaları

\begin{tabular}{ccc}
\hline Not Ortalamaları & $\mathrm{f}$ & $\%$ \\
\hline $0-2.99$ & 83 & 38.4 \\
$3.00-4.00$ & 133 & 61.6 \\
\hline
\end{tabular}

Tablo 3 incelendiğinde araştırmaya katılan öğretmen adaylarının \%38.4'ünün 0-2.99, \%61.6'sının 3.00-4.00 arası not ortalamasına sahip olduğu görülmektedir.

Tablo 4. Araştırmaya Katılanların Sınıf Düzeyleri

\begin{tabular}{ccc}
\hline Sinif & f & $\%$ \\
\hline 1. Sinif & 36 & 16,7 \\
2. Sinif & 22 & 10,2 \\
3. Sinif & 84 & 38,9 \\
4. Sinif & 74 & 34,3 \\
\hline
\end{tabular}

Tablo 4 incelendiğinde araștırmaya katılanların \%16.7'si 1., \%10.2'si 2., \%38.9'unun 3., \%34.3'nün ise 4. sinıf olduğu tespit edilmiştir.

Tablo 5. Araştırmanın Örneklem Grubunun İnternette Geçirdikleri Süre

\begin{tabular}{ccc}
\hline İnternette Geçirilen Süre & $\mathrm{f}$ & $\%$ \\
\hline $0-2$ saat & 16 & 7,4 \\
$2-3$ saat & 18 & 8,3 \\
$3-4$ saat & 50 & 23,1 \\
$4-5$ saat & 47 & 21,8 \\
5 saatten fazla & 85 & 39,4 \\
\hline
\end{tabular}

Tablo 5 incelendiğinde araştırmanın örneklem grubunun \%7.4'ü 0-2 saat, \%8.3'ü 2-3 saat, \%23.1'i 3-4 saat, \%21.8'i 4-5 saat, \%39.4'ü ise 5 saatten fazla internette vakit geçirdiği ifade etmiştir.

\section{Veri Toplama Araçları}

Araştırmada Bolat ve Balaman (2017) tarafından geliştirilen "Yaşam Becerileri Ölçeği”" kullanılmıştır. Ölçek 30 madde ve 5 faktörden (Stres ve duygular ile başa çıkma, özfarkındalık ve empati, problem çözme ve karar verme, eleştirel ve yaratıcı düşünme, kişiler arası ilişki ve iletişim) oluşmaktadır. 
Araştırmada kullanılan ölçek toplam varyansın \%61'ini açıklamaktadır. Ölçeğin Kaiser-Meyer-Olkin $(\mathrm{KMO}=.917)$, Bartlett testi $\left(\mathrm{x}^{2}=3757,324\right.$; sd=435, $\left.\mathrm{p}=.000\right)$ ölçeğin yap1 geçerliğinin uygun olduğu görülmüştür. Ölçeğin iç tutarlılık katsayısı .93'tür. Bu analizler dikkate alındığında ölçeğin geçerli ve güvenilir olduğu görülmüştür.

\section{Veri Analizi}

Araştırmada öncelikle verilerin basıklık ve çarpıklık değerlerine bakılmıştır. Şencan (2005) verilerin normal dağılım gösterebilmesi için bu değerlerin -2 ile +2 arasında olması gerektiğini belirtmektedir.

Tablo 6. Ölçeğe Ait Çarpıklık ve Basıklık Değerleri

\begin{tabular}{lcc}
\hline \multicolumn{1}{c}{ Boyutlar } & Çarpıklık & Basıklık \\
\hline Duygularla ve Stresle Başa Çıkma Becerileri &,- 107 &,- 431 \\
Empati Kurma ve Özfarkındalık Becerileri &,- 429 &,- 319 \\
Karar Verme ve Problem Çözme Becerileri &,- 854 &, 473 \\
Yaratıcı Düşünme ve Eleştirel Düşünce Becerileri & $-1,020$ & 1,534 \\
İletişim Kişilerarası İlişki Becerileri &,- 800 &, 229 \\
\hline
\end{tabular}

Tablo 6 incelendiğinde veriler normal dağılım gösterdiği için betimsel analiz, t-testi, ANOVA, koelasyon analizi yapılmıştır.

\section{BULGULAR}

Araştırmanın bu bölümünde elde edilen veriler analiz edilmiştir.

Tablo 7. Ölçekte Yer Alan Boyutlara Ait Tanımlayııı İstatistik Analizleri

\begin{tabular}{llc}
\hline \multicolumn{1}{c}{ Maddeler } & $\overline{\mathrm{x}}$ & $\mathrm{ss}$ \\
\hline Duygularla ve Stresle Başa Çıkma Becerileri & 3,47 &, 766 \\
Empati Kurma ve Özfarkındalık Becerileri & 4,06 &, 641 \\
Karar Verme ve Problem Çözme Becerileri & 4,14 &, 688 \\
Yaratıcı Düşünme ve Eleştirel Düşünce Becerileri & 4,25 &, 654 \\
İletişim Kişilerarası İlişki Becerileri & 4,29 &, 611 \\
\hline
\end{tabular}

Tablo 7 incelendiğinde Türkçe öğretmeni adayları, duygularla ve stresle başa çıkma konusunda kararsız olduklarını; empati kurma, özfarkındalık, karar verme, problem çözme, yaratıcı düşünme, eleştirel düşünce, iletişim, kişilerarası ilişki becerileri konusunda kendilerini yeterli gördüklerini belirtmektedirler. 
Tablo 8. Yaşam Becerileri Ölçeğinde Yer Alan Boyutlara İlişkin Cinsiyete Göre t-testi Sonuçları

\begin{tabular}{cccccccc}
\hline Boyut & Cinsiyet & $\mathrm{n}$ & Ortalama & $\mathrm{ss}$ & $\mathrm{t}$ & $\mathrm{df}$ & $\mathrm{p}$ \\
\hline Duygularla ve Stresle & Kadın & 150 & 3,42 &, 770 & - & 214 &, 240 \\
Başa Çıkma Becerileri & Erkek & 66 & 3,56 &, 753 & & & \\
Empati Kurma ve & Kadın & 150 & 4,07 &, 657 &, 562 & 214 & \multirow{2}{*}{, 575} \\
Özfarkındalık Becerileri & Erkek & 66 & 4,02 &, 607 & & & \\
Karar Verme ve Problem & Kadın & 150 & 4,15 &, 699 &, 287 & 214 &, 774 \\
Çözme Becerileri & Erkek & 66 & 4,12 &, 667 & & & \\
Yaratııı Düşünme ve & Kadın & 150 & 4,26 &, 676 &, 303 & 214 &, 762 \\
Eleștirel Düşünce & Erkek & 66 & 4,23 &, 607 & & & \\
$\quad$ Becerileri & & & & & & \\
İletişim Kişilerarası İlişki & Kadın & 150 & 4,34 &, 597 & 1,759 & 214 &, 080 \\
Becerileri & Erkek & 66 & 4,18 &, 634 & & & \\
\hline
\end{tabular}

Tablo 8 incelendiğinde Türkçe öğretmeni adaylarının yaşam beceri ile ilgili görüşleriyle cinsiyetleri arasında anlamlı bir ilişkinin olmadığ görülmektedir.

Tablo 9. Yaşam Becerileri Ölçeğinde Yer Alan Maddelere İlişkin Cinsiyete Göre t-testi Sonuçları

\begin{tabular}{lccccccc}
\hline \multicolumn{1}{c}{ Madde } & Cinsiyet & $\mathrm{n}$ & Ortalama & $\mathrm{ss}$ & $\mathrm{t}$ & $\mathrm{df}$ & $\mathrm{p}$ \\
\hline $\begin{array}{l}\text { 3. Olumsuz } \\
\text { duygularımı } \\
\text { çevremdeki }\end{array}$ & Kadın & 150 & 3,29 & 1,195 & - & 214 &, 024 \\
$\begin{array}{l}\text { insanlara } \\
\text { yansıtmayabilirim. }\end{array}$ & Erkek & 66 & 3,69 & 1,214 & 2,274 & & \\
$\begin{array}{l}\text { 11. Kendimi } \\
\text { karşımdaki bireyin } \\
\text { yerine koyabilirim. }\end{array}$ & Kadın & 150 & 4,49 &, 730 & 2,167 & 214 &, 031 \\
$\begin{array}{l}\text { 20. Konuşma anında } \\
\text { kullanacağım }\end{array}$ & Kadın & 150 & 4,40 &, 724 & 2,245 & 214 &, 026 \\
$\begin{array}{l}\text { iletişim araçlarına } \\
\text { karar verebilirim. }\end{array}$ & Erkek & 66 & 4,15 &, 863 & & & \\
$\begin{array}{l}\text { 30. İletişim ortamını } \\
\text { bozmamak adına } \\
\text { konuşma sırasını } \\
\text { bekleyebilirim }\end{array}$ & Kadın & 150 & 4,52 &, 682 & 2,603 & 214 &, 010 \\
\hline
\end{tabular}

Tablo 9 incelendiğinde erkek öğretmen adayları kadın öğretmen adaylarına göre olumsuz duygularını çevresindeki insanlara yansıtmayabilmektedirler. Kadın öğretmen adayları erkek öğretmen adaylarına göre kendilerini 
karşılarındaki bireyin yerine koyabilmekte, konuşma anında kullanabilecekleri iletişim araçlarına karar verebilmekte, iletişim ortamını bozmamak adına konuşma sırasını bekleyebilmektedir.

Tablo 10. Yaşam Becerileri Ölçeğinde Yer Alan Boyutlara İlişkin not Ortalamasına Göre t-testi Sonuçları

\begin{tabular}{|c|c|c|c|c|c|c|c|}
\hline Boyut & $\begin{array}{c}\text { Not } \\
\text { Oratalamas1 }\end{array}$ & $\mathrm{n}$ & Ortalama & ss & $\mathrm{t}$ & $\mathrm{df}$ & $\mathrm{p}$ \\
\hline Duygularla ve & $0-2.99$ & 83 & 3,48 & ,769 & 177 & 214 & 860 \\
\hline Stresle Başa & $3.00-4.00$ & 133 & 3,46 & ,767 & & & \\
\hline Çıkma Becerileri & & & & & & & \\
\hline $\begin{array}{l}\text { Empati Kurma } \\
\text { ve Özfarkındalık }\end{array}$ & $0-2.99$ & 83 & 3,98 & ,701 & $\begin{array}{c}- \\
1,384\end{array}$ & 214 & 168 \\
\hline Becerileri & $3.00-4.00$ & 133 & 4,10 & ,598 & & & \\
\hline Karar Verme ve & $0-2.99$ & 83 & 4,05 & ,797 & - & 214 & 130 \\
\hline Problem Çözme & & & & & 1,521 & & \\
\hline Becerileri & $3.00-4.00$ & 133 & 4,19 & ,606 & & & \\
\hline Yaratıcı & $0-2.99$ & 83 & 4,16 & ,775 & - & 214 & 102 \\
\hline Düşünme ve & & & & & 1,643 & & \\
\hline $\begin{array}{l}\text { Eleştirel Düşünce } \\
\text { Becerileri }\end{array}$ & $3.00-4.00$ & 133 & 4,31 & ,561 & & & \\
\hline İletişisim & $0-2.99$ & 83 & 4,27 & 639 &,- 276 & 214 & 783 \\
\hline $\begin{array}{l}\text { Kişilerarası İlişki } \\
\text { Becerileri }\end{array}$ & $3.00-4.00$ & 133 & 4,30 & ,596 & & & \\
\hline
\end{tabular}

Tablo 10 incelendiğinde Türkçe öğretmeni adaylarının yaşam beceri ile ilgili görüşleriyle not ortalamaları arasında anlamlı bir ilişkinin olmadığ 1 görülmektedir.

Tablo 11. Yaşam Becerileri Ölçeğinde Yer Alan Maddelere İlişkin Not Ortalamasına Göre t-testi Sonuçları

\begin{tabular}{lccccccc}
\hline \multicolumn{1}{c}{ Madde } & $\begin{array}{c}\text { Not } \\
\text { Oratalaması }\end{array}$ & $\mathrm{n}$ & Ortalama & $\mathrm{ss}$ & $\mathrm{t}$ & $\mathrm{df}$ & $\mathrm{p}$ \\
\hline $\begin{array}{l}\text { 3. Olumsuz } \\
\text { duygularımı }\end{array}$ & $0-2.99$ & 83 & 3,67 & 1,105 & 2,499 & 214 &, 013 \\
$\begin{array}{l}\text { çevremdeki insanlara } \\
\text { yansıtmayabilirim. }\end{array}$ & $3.00-4.00$ & 133 & 3,25 & 1,253 & & & \\
$\begin{array}{l}\text { 5. İs stresini } \\
\text { engellemek için bir }\end{array}$ & $0-2.99$ & 83 & 3,51 & 1,213 & - & 214 &, 015 \\
$\begin{array}{l}\text { plan dâhilinde } \\
\text { çalışabilirim. }\end{array}$ & $3.00-4.00$ & 133 & 3,87 &, 945 & & & \\
$\begin{array}{l}\text { 12. Duygularıma dair } \\
\text { bilinçli bir }\end{array}$ & $0-2.99$ & 83 & 4,01 &, 943 & - & 214 &, 015 \\
& & & & & 2,446 & &
\end{tabular}




\begin{tabular}{|c|c|c|c|c|c|c|c|}
\hline $\begin{array}{l}\text { farkındalık } \\
\text { geliştirebilirim. }\end{array}$ & $3.00-4.00$ & 133 & 4,29 & ,736 & & & \\
\hline 19. Grupça bir konu & $0-2.99$ & 83 & 3,93 & 1,051 & - & 214 & ,017 \\
\hline $\begin{array}{l}\text { hakkında kararlar } \\
\text { alabilirim. }\end{array}$ & $3.00-4.00$ & 133 & 4,24 & 820 & 2,407 & & \\
\hline $\begin{array}{l}\text { 20. Konuşma anında } \\
\text { kullanacağım }\end{array}$ & $0-2.99$ & 83 & 4,16 & ,838 & $\begin{array}{l}- \\
2,419\end{array}$ & 214 & ,016 \\
\hline $\begin{array}{l}\text { iletişim araçlarına } \\
\text { karar verebilirim. }\end{array}$ & $3.00-4.00$ & 133 & 4,42 & ,720 & & & \\
\hline $\begin{array}{l}\text { 21. Problem çözme } \\
\text { planımın adımlarını }\end{array}$ & $0-2.99$ & 83 & 3,96 & 1,064 & $\begin{array}{c}- \\
2,769\end{array}$ & 214 & ,006 \\
\hline uygulayabilirim. & $3.00-4.00$ & 133 & 4,30 & ,760 & & & \\
\hline $\begin{array}{l}\text { 22. Sorunlara karş1 } \\
\text { duyarlılık }\end{array}$ & $0-2.99$ & 83 & 4,04 & 1,010 & 2,446 & 214 & ,015 \\
\hline gösterebilirim. & $3.00-4.00$ & 133 & 4,35 & ,809 & & & \\
\hline $\begin{array}{l}\text { 25. Olaylar arasında } \\
\text { neden-sonuç }\end{array}$ & $0-2.99$ & 83 & 4,20 & 907 & $\begin{array}{c}- \\
2,273\end{array}$ & 214 & ,024 \\
\hline işkisini kurabilirim & $3.00-4.00$ & 133 & 4,45 & ,679 & & & \\
\hline
\end{tabular}

Tablo 11 incelendiğinde not ortalaması 0-2.99 arası olan Türkçe öğretmeni adayları, not ortalamas 13.00-4.00 arası olan öğretmen adaylarına göre olumsuz duygularını çevresindeki insanlara yansıtmadıklarını dile getirmektedirler. Not ortalaması 3.00-4.00 arası olan Türkçe öğretmeni adayları, not ortalaması 0-2.99 arası olan öğretmen adaylarına göre iş stresini engellemek için bir plan dâhilinde çalışabilmekte, duygularıma dair bilinçli bir farkındalık geliştirebilmekte, grupça bir konu hakkında kararlar alabilmekte, konuşma anında kullanacakları iletişim araçlarına karar verebilmekte, problem çözme planımın adımlarını uygulayabilmekte, sorunlara karşı duyarlılık gösterebilmekte, olaylar arasında neden-sonuç ilişkisini kurabilmektedir.

Tablo 12. Türkçe Öğretmeni Adaylarının Yaşları ile Yaşam Becerileri Ölçeği Boyutları Arasındaki ANOVA Sonuçları

\begin{tabular}{cccccc}
\hline Madde & $\begin{array}{c}\text { Varyansın } \\
\text { Kaynağı }\end{array}$ & sd & F & P & $\begin{array}{c}\text { Anlamlı } \\
\text { Farklılık }\end{array}$ \\
\hline Duygularla ve & Gruplar arası & 3 & 4,698 &, 003 & \\
Stresle Başa & Gruplar içi & 212 & & & A-B \\
Çıkma & Toplam & 215 & & & \\
Becerileri & Gruplar arası & 3 &, 514 &, 673 & \\
Empati Kurma & Gruplar içi & 212 & & & \\
ve Özfarkındalık & Toplam & 215 & & & \\
Becerileri & Gruplar arası & 3 & 1,279 & \multirow{2}{*}{283} & \\
Karar Verme ve & Gruplar içi & 212 & & & \\
Problem Çözme & Toplam & 215 & & & \\
Becerileri & Toplam & & &
\end{tabular}




\begin{tabular}{ccccc}
\hline Yaratıc1 & Gruplar arası & 3 &, 558 & ,643 \\
Düşünme ve & Gruplar içi & 212 & & \\
Eleştirel & & 215 & & \\
Düşünce & Toplam & & & \\
Becerileri & & & & \\
İletişim & Gruplar arası & 3 &, 407 &, 748 \\
Kişilerarası & Gruplar içi & 212 & & \\
İlişki Becerileri & Toplam & 215 & & \\
\hline$A=18-19 ; B=20-21 ; C=22-23 ; D=24$ ve üzeri
\end{tabular}

Tablo 12 incelendiğinde Türkçe öğretmeni adaylarının empati kurma ve özfarkındalık ( $\mathrm{F}=.514 ; \mathrm{p}>.05)$, karar verme ve problem çözme $(\mathrm{F}=1.279 ; \mathrm{p}>.05)$, yaratıcı düşünme ve eleştirel düşünce $(\mathrm{F}=.558 ; \mathrm{p}>.05)$, iletişim kişilerarası ilişki $(\mathrm{F}=.407 ; \mathrm{p}>.05)$ becerileri ile yaşları arasında anlamlı bir ilişkinin olmadığ 1 görülmektedir. Türkçe öğretmeni adaylarının duygularla ve stresle başa çıkma becerileri $(\mathrm{F}=4,698 ; \mathrm{p}<.05)$ ile yaşları arasında bir ilişkinin olduğu görülmektedir. 18-19 yaş aralığındaki Türkçe öğretmeni adayları 20-21 yaş aralığındaki Türkçe ögrretmeni adaylarına göre duygularla ve stresle başa çıkabildiklerini ifade etmektedirler.

Tablo 13. Türkçe Öğretmeni Adaylarının Yaşları ile Yaşam Becerileri Ölçeğinde Yer Alan Maddeler Arasındaki ANOVA Sonuçları

\begin{tabular}{lccccc}
\hline \multicolumn{1}{c}{ Madde } & $\begin{array}{c}\text { Varyansın } \\
\text { Kaynağ1 }\end{array}$ & sd & F & p & $\begin{array}{c}\text { Anlamll } \\
\text { Farklılık }\end{array}$ \\
\hline 13. Problemle başa çıkabilmek & Gruplar arası & 3 & 2,812 &, 040 & \\
için risk alabilirim. & Gruplar içi & 212 & & & C-B \\
Toplam & 215 & & & \\
16. Bir karar anında bütün & Gruplar arası & 3 & 3,195 &, 024 & \\
sorumlulukları üzerime & Gruplar içi & 212 & & & D-A \\
alabilirim. & Toplam & 215 & & & \\
19. Grupça bir konu hakkında & $\begin{array}{c}\text { Gruplar arası } \\
\text { Gruplar içi }\end{array}$ & 212 & 2,862 &, 038 & \\
kararlar alabilirim & Toplam & 215 & & & C-A \\
\hline
\end{tabular}

$A=18-19 ; B=20-21 ; C=22-23 ; D=24$ ve üzeri

Tablo 13 incelendiğinde 22-23 yaş aralığındaki Türkçe öğretmeni adayları, 20-21 yaş aralı̆̆ındaki Türkçe öğretmeni adaylarına göre problemle başa çıkabilmek için rsik alabileceğini belirtmektedir. 24 ve üzeri yaş aralığındaki Türkçe öğretmeni adayları 18-19 yaş aralığındaki Türkçe öğretmeni adaylarına göre bir karar anında bütün sorumlulukları üzerime alabileceklerini ifade etmektedir. 22-23 yaş aralığındaki Türkçe öğretmeni adayları 18-19 yaş aralığındaki Türkçe öğretmeni adaylarına göre grupça bir konu hakkında kararlar alabileceklerini dile getirmektedir. 
Tablo 14. Türkçe Öğretmeni Adaylarının Sınıf Düzeyleriyle Yaşam Becerileri Ölçeği Boyutları Arasındaki ANOVA Sonuçları

\begin{tabular}{|c|c|c|c|c|}
\hline Madde & Varyansın Kaynağı & sd & $\mathrm{F}$ & $\mathrm{p}$ \\
\hline Duygularla ve & Gruplar aras1 & 3 & 879 & 453 \\
\hline Stresle Başa Çıkma & Gruplar içi & 212 & & \\
\hline Becerileri & Toplam & 215 & & \\
\hline Empati Kurma ve & Gruplar aras1 & 3 & 135 & ,939 \\
\hline Özfarkındalık & Gruplar içi & 212 & & \\
\hline Becerileri & Toplam & 215 & & \\
\hline Karar Verme ve & Gruplar aras1 & 3 & 1,628 & 184 \\
\hline Problem Çözme & Gruplar içi & 212 & & \\
\hline Becerileri & Toplam & 215 & & \\
\hline Yaratıcı Düşünme & Gruplar aras1 & 3 & 2,535 & 058 \\
\hline ve Eleştirel Düşünce & Gruplar içi & 212 & & \\
\hline Becerileri & Toplam & 215 & & \\
\hline İletişim & Gruplar arası & 3 & 910 & 437 \\
\hline Kişilerarası İlişki & Gruplar içi & 212 & & \\
\hline Becerileri & Toplam & 215 & & \\
\hline
\end{tabular}

$A=1 ; B=2 ; C=3 ; D=4$

Tablo 14 incelendiğinde Türkçe öğretmeni adaylarının duygularla ve stresle başa çıkma becerileri $(\mathrm{F}=.879 ; \mathrm{p}<.05)$, empati kurma ve özfarkındalık $(\mathrm{F}=.315$; $\mathrm{p}>.05)$, karar verme ve problem çözme $(\mathrm{F}=1.628 ; \mathrm{p}>.05)$, yaratıcı düşünme ve eleştirel düşünce $(\mathrm{F}=2.535 ; \mathrm{p}>.05)$, iletişim kişilerarası ilişki $(\mathrm{F}=.910 ; \mathrm{p}>.05)$ becerileri ile sınıf düzeyleri arasında anlamlı bir ilişkinin olmadığı görülmektedir.

Tablo 15. Türkçe Öğretmeni Adaylarının Sınıf Düzeyleriyle ile Yaşam Becerileri Ölçeğinde Yer Alan Maddeler Arasındaki ANOVA Sonuçları

\begin{tabular}{|c|c|c|c|c|c|}
\hline Madde & $\begin{array}{c}\text { Varyansin } \\
\text { Kaynağ } 1\end{array}$ & sd & $\mathrm{F}$ & $\mathrm{p}$ & $\begin{array}{l}\text { Anlaml1 } \\
\text { Farklı11k }\end{array}$ \\
\hline 18. Bir konu hakkında vereceğim & Gruplar aras1 & 3 & 3,078 & 029 & \\
\hline $\begin{array}{l}\text { kararların sonuçlarını tahmin } \\
\text { edebilirim. }\end{array}$ & Gruplar içi & 212 & & & B-A \\
\hline $\begin{array}{l}\text { 22. Sorunlara karşı duyarlılık } \\
\text { gösterebilirim. }\end{array}$ & $\begin{array}{l}\text { Gruplar aras } 1 \\
\text { Gruplar içi } \\
\text { Toplam }\end{array}$ & $\begin{array}{c}3 \\
212 \\
215\end{array}$ & 3,778 & 011 & D-A \\
\hline $\begin{array}{l}\text { 25. Olaylar arasında neden-sonuç } \\
\text { ilişkisini kurabilirim. }\end{array}$ & $\begin{array}{l}\text { Gruplar aras } 1 \\
\text { Gruplar içi } \\
\text { Toplam }\end{array}$ & $\begin{array}{c}3 \\
212 \\
215 \\
\end{array}$ & 2,682 & ,048 & B-A \\
\hline
\end{tabular}

$A=1 ; B=2 ; C=3 ; D=4$

Tablo 15 incelendiğinde 2. sınıf Türkçe öğretmeni adayları, 1. sınıf Türkçe öğretmeni adaylarına göre bir konu hakkında vereckleri kararların sonuçlarını tahmin edebildiklerini, olaylar arasında neden-sonuç ilişkisini kurabildiklerini 
düşünmektedirler. 4. sınıf Türkçe öğretmeni adayları, 1. sınıf Türkçe öğretmeni adaylarına göre sorunlara karşı duyarlılık gösterebildiklerini belirtmektedirler.

Tablo 16. Türkçe Öğretmeni Adaylarının İnternette Geçirdikleri Süre Yaşam Becerileri Ölçeği Boyutları Arasındaki ANOVA Sonuçları

\begin{tabular}{ccccc}
\hline Madde & Varyansın Kaynağı & sd & F & p \\
\hline Duygularla ve & Gruplar arası & 4 &, 210 &, 933 \\
Stresle Başa Çıma & Gruplar içi & 211 & & \\
Becerileri & Toplam & 215 & & \\
Empati Kurma ve & Gruplar arası & 4 &, 811 &, 519 \\
Özfarkındalık & Gruplar içi & 211 & & \\
Becerileri & Toplam & 215 & & \\
Karar Verme ve & Gruplar arası & 4 & 1,346 &, 254 \\
Problem Çözme & Gruplar içi & 211 & & \\
Becerileri & Toplam & 215 & & \\
Yaratıı Düşünme & Gruplar arası & 4 &, 311 &, 870 \\
ve Eleştirel Düşünce & Gruplar içi & 211 & & \\
Becerileri & Toplam & 215 & & \\
İletişim & Gruplar arası & 4 &, 844 &, 499 \\
Kişilerarası İlişki & Gruplar içi & 211 & & \\
Becerileri & Toplam & 215 & & \\
\hline
\end{tabular}

$A=0-2 ; B=2-3 ; C=3-4 ; D=4-5 ; E=5$ ve üzeri

Tablo 16 incelendiğinde Türkçe öğretmeni adaylarının duygularla ve stresle başa çıkma becerileri $(\mathrm{F}=.210 ; \mathrm{p}<.05)$, empati kurma ve özfarkındalık $(\mathrm{F}=.811$; $\mathrm{p}>.05)$, karar verme ve problem çözme $(\mathrm{F}=1.346 ; \mathrm{p}>.05)$, yaratıcı düşünme ve eleştirel düşünce $(\mathrm{F}=.311 ; \mathrm{p}>.05)$, iletişim kişilerarası ilişki $(\mathrm{F}=.844 ; \mathrm{p}>.05)$ becerileri ile internette geçirdikleri süre arasında anlamlı bir ilişkinin olmadığ 1 görülmektedir.

\section{TARTIŞMA VE SONUÇ}

21. yüzy1lda bireylerin okulda öğrendiklerini gerçek yaşamda uygulayabilmeleri çok önemlidir. Bireyler sadece ezbere eğitim almamalı, yaşam becerilerini geliştirmelidir. Cassidy, Franco ve Meo (2018), yaşam becerilerinin insan hayatından çok önemli olduğunu vurgulamıştır. Öğretmen eğitiminde yaşam becerileri konusunda verilen eğitim çok önemlidir. Yaşam becerileri insan hayatını yönlendiren çok yöneli bir beceridir (Spence, 2003). Türkçe öğretmeni adayları, duygularla ve stesle başa çıkma becerileri konusunda kendilerini bazen yeterli bazense yetersiz gördüklerini belirtmektedirler. Türkçe öğretmeni adayları stresle başa çıkma yollarını kullanabilecekleri, stresi yapacakları işler için olumlu kullanma, olumsuz duygularla başa çıkabilme, iş stresini engellemek için bir plan dahilinde çalışabilme, stres karşısında mizah unsurlarını kullanabilme, stresi artıracak mükemmelliyetçilik duygusundan vazgeçebilme konusunda kararsız 
olduklarını belirtmişlerdir. Türkçe öğretmeni adayları bireylerle empati kurabildiklerini, öz farkındalık becerilerinin yüksek olduğunu, neleri başarabileceğini fark edebildiklerini, ilgi alanlarına yönelebildiklerini, kendilerini, karşılarındaki bireyin yerine koyabildiklerini, duygularına dair bilinçli bir farkındalık geliştirebildiklerini, problemle başa çıkabilmek için risk alabildiklerini, yapmaktan hoşlanmadıkları aktivitelerle ilgili farklı alternatifler düşünebildiklerini dile getirmişlerdir. Türkçe öğretmeni adayları sorumluluk duygusuna sahip olduklarını, verdiği kararlarla ilgili sonuçları tahmin edebildiklerini, konuşma anında kullanabilecekleri konuşma araçlarına karar verebildiklerini ve problem çözme planlarının adımlarını uygulayabileceklerini ifade etmişlerdir. Öğretmen adayları sorunlara karşı duyarlı1ık gösterebildiklerini, sorunlarının nedenlerini tespit edebildiklerini, olaylar arasında neden-sonuç ilişkisi kurabildiklerini, olaylar karşısında analitik çözümler üretebildiklerini belirtmişlerdir. Türkçe öğretmeni adayları iletişim ortamını bozmamak adına konuşma sırasını bekleyebildiklerini, konuşma esnasına konuştuğu kişiye tolerans sağlayabileceklerini, kişisel iletişim becerilerine uygun bir şekilde hareket edebileceklerini dile getirmişlerdir. Türkçe öğretmeni adayları yaşam becerilerini sahip olduklarını ve bu becerileri günlük hayatta kullanabildiklerini ifade etmektedirler. Külekçi Akyavuz ve Karakaş (2020) araştırmalarında öğretmen adaylarının yaşam becerisi düzeylerini yüksek bulmuştur. Yılmaz (2019) araştırmasından öğretmen adaylarının yaşam becerileri içerisinde yer alan stresle başa çıkma düzeylerinin yüksek olduğunu tespit etmiş̧ir. Zorlu, Zorlu ve Dinç (2019) araştırmalarında öğretmen adaylarının yaşam becerilerinin orta seviyede olduğunu belirtmişlerdir. Ursavaş ve Karal (2019) araştırmalarında öğretmenlerin yaşam becerilerini bilmediklerini, bu konuda eksik olduklarını ifade etmektedir. Aynı şekilde Erduran ve Kamer (2018) araştırmalarında öğretmenlerin yaşam becerileri farkındalık düzeylerinin düşük olduğunu vurgulamıştır. Calp ve Edis (2020) araştırmalarında sınıf öğretmenlerinin yaşam becerileri kazanmada kendilerini özyeterli olarak gördüklerini, öğretmenlerin en çok üzerinde durduğu yaşam becerisinin problem çözme becerisi olduğunu ifade etmişlerdir.

Türkçe öğretmeni adaylarının yaşam beceri ile ilgili görüşleriyle cinsiyetleri arasında anlamlı bir ilişki vardır. Erkek öğretmen adayları olumsuz duygularını çevreye yansıtmadıklarını, çevreye karşı olumlu göründüklerini belirtmektedirler. Kadın öğretmen adayları ise çevresiyle empati kurabildiklerini, konuşma anında insanlarla hangi iletişim aracı yoluyla iletişim kurabileceğini iyi bildiklerini, iletişim esnasında sıralarını beklediklerini belirtmişlerdir. Türkçe öğretmeni adaylarının yaşam beceri ile ilgili görüssleriyle not ortalamaları arasında anlamlı bir ilişki vardır. Not ortalaması orta seviyede olan ögretmen adayları, olumsuz duygularını çevrelerine yansıtmamaktadırlar. Not ortalaması yüksek olan ögretmen adayları stresten kurtulmak için bir plan dahilinde çalı̧̧abildiklerini, duygularıyla ilgili bilinçli bir farkındalıklarının olduğunu, 
arkadaş grubuyla birlikte karar alabildiklerini, konuşma anında karşıdakine en uygun iletişim aracını kullanabildiklerini, problem çözmenin adımlarını uygulayabildiklerini, sorunlara karşı duyarlık gösterebildiklerini, olayalar arasında neden-sonuç ilişkisi kurabildiklerini dile getirmişlerdir. Türkçe öğretmeni adaylarının yaşam beceri ile ilgili görüşleriyle yaşları arasında anlamlı bir ilişki vardır.18-19 yaş aralığındaki Türkçe öğretmeni adayları stress ve duyguyla başa çıkabildiklerini ifade etmişlerdir. 22 ve üzeri yaş dilimindeki öğretmen adayları karar anında sorumluluk alabildiklerini, grupça kararlar alabildiklerini ifade etmişlerdir. 22-23 aralığındaki Türkçe öğretmeni adayları problemle başa çıkabilmek için risk alabildiklerini belirtmişlerdir. Türkçe öğretmeni adaylarının yaşam beceri ile ilgili görüşleriyle sınıf düzeyleri arasında anlamlı bir ilişki vardır. 2. sınıf Türkçe öğretmeni adayları bir konu hakkındaki verecekleri kararların sonuçlarını tahmin edebildiklerini, olaylar arasında nedensonuç ilişkisi kurabildiklerini belirtmişlerdir. 4. Sınıf öğretmen adayları ise sonuçlara karşı duyarlı olduklarını belirtmektedirler. Türkçe öğretmeni adaylarının yaşam beceri ile ilgili görüşleriyle internette geçirdikleri süre arasında anlamlı bir ilişki yoktur.

\section{KAYNAKÇA}

Bahçeci, D. ve Kuru, M. (2008). Portfolyo değerlendirmenin üniversite öğrencilerinin öz-yeterlik algısı ve yaşam becerileri üzerine etkisi. Ahi Evran Üniversitesi Kırşehir Ë̆itim Fakültesi Dergisi (KEFAD), 9(1), 9711.

Calp, Ş. ve Edis, A. (2020). Sınıf öğretmenlerinin yaşam becerileri ile ilgili bilgi ve deneyimleri. Nevşehir Hacı Bektaş Veli Üniversitesi SBE Dergisi, 10(2), 549-565.

Cassidy, K., Franco, Y. ve Meo, E. (2018). Preparation for adulthood: A teacher inquiry study for facilitating life skills in secondary education in the united states. Journal of Education Issues, 4(1), 33-45. https://doi.org/10.5296/jei.v4i1.12471

Deveci, İ., Konuş, F. Z. ve Aydız, M. (2018). 2018 yılı fen bilimleri dersi öğretim programı kazanımlarının yaşam becerileri açısından incelenmesi. Çukurova Üniversitesi Eğitim Fakültesi Dergisi, 47(2), 765-797. https://doi.org/10.14812/cuefd.413514

Avc1, D. E. ve Kamer, D. (2018). Views of teachers regarding the life skills provided in science curriculum. Euroasian Journal of Educational Research, 77, 1-18. 
Bolat, Y. ve Balaman, F. (2017). Yaşam becerileri ölçeği: Geçerlik ve güvenirlik çalışması. İnsan ve Toplum Bilimleri Araştırmaları Dergisi, 6(4), 22-39

Güleç, V. K. (2020). Sinıf ögretmenlerinin yaşam becerileriyle eğitsel değerleri arasındaki ilişkinin incelenmesi (Afyonkarahisar İli Örneklemi) [Yayımlanmamış yüksek lisans tezi]. Afyon Kocatepe Üniversitesi.

Karasar, N. (2013). Bilimsel araştırma yöntemi. (25. bask1), Nobel Yayıncılık.

Kivunja, C. (2015). Teaching students to learn and to work well with 21st century skills: unpacking the career and life skills domain of the new learning paradigm. International Journal of Higher Education, 4(1), 1-11. http://dx.doi.org/10.5430/ijhe.v4n1p1

Külekçi Akyavuz, E. ve Karakaş, A. (2020). Öğretmen adaylarının yaşam becerilerinin incelenmesi. Uluslararası Türkçe Edebiyat Kültür Eğitim (TEKE) Dergisi, 9(4), 1832-1851.

P21. (2009, April 18). P21 framework definitions. Partnership for 21st century skills (P21)”, http://www.21stcenturyskills.org.

Spence, S. H. (2003). Social skills training with children and young people: theory, evidence and practice. Child and Adolascent Mental Health, 8(2), 84-96.

Şencan, H. (2005). Sosyal ve davranışsal ölçümlerde güvenilirlik ve geçerlilik. Seçkin Yayıncılık.

Bilir, T.Z. (2019). Yaşam becerileri programının beş yaş çocuklarının yaşam becerileri, benlik algıları ve sosyal duygusal uyum düzeylerine etkisi [Yayımlanmamış doktora tezi]. Hacettepe Üniversitesi.

Ulus, L. (2018). Ergen bireyler için yaşam becerileri. Avrasya Sosyal ve Ekonomi Araştırmaları Dergisi, 5(12), 516-537.

Ursavas, N. ve Karal, E. (2019). Fen bilimleri öğretmenlerinin yaşam becerileri hakkındaki düşünceleri ve fen kazanımlarıyla ilişkilendirme durumları. Akdeniz Eğitim Araştırmaları Dergisi, 13(30), 246-269.

Ümmet, D. ve Demirci, G. (2017). Yaşam becerileri eğitimi kapsamında yürütülen grupla psikolojik danışma uygulamasının ortaokul öğrencilerinin iyi oluşları üzerindeki etkisi. Marmara Üniversitesi Atatürk Eğitim Fakültesi Eğitim Bilimleri Dergisi, 45, 153-170. https://doi.org/10.15285/maruaebd.263879 
World Health Organization [WHO] (1999). Partners in life skills education. Department of Mental Health World Health Organization, Geneva.

Sezgin, E. Y. (2018). Okul öncesi dönemde yaşam becerileri. Avrasya Sosyal ve Ekonomi Araştırmaları Dergisi, 5(12), 710-719.

Eskici, G. Y. ve Özsevgeç, T. (2019). Yaşam becerileri ile ilgili çalışmaların tematik içerik analizi: Bir meta-sentez çalışması. International e-Journal of Educational Studies, 3(5),1-15. https://doi.org/10.31458/iejes.421255

Yıldırım, Y. ve Temel, Z. F. (2020). Yaşam becerileri eğitim programının anasınıfına devam eden çocukların yaşam becerilerine ve sosyal uyumlarına etkisinin incelenmesi. Yaşadıkça Eğitim, 34(2), 384-405. https://doi.org/10.33308/26674874.2020342212

Yılmaz, A. (2019). Öğretmen adaylarının kariyer streslerinin karma araştırma yaklaşımı ile incelenmesi. Türk Spor Bilimleri Dergisi, 2(1), 93-105.

Zorlu, Y., Zorlu, F. ve Dinç, S. (2019). Fen bilgisi öğretmen adaylarının yaşam becerileri ile bilişüstü farkındalıkları arasındaki ilişkilerin incelenmesi. Necatibey Eğitim Fakültesi Elektronik Fen ve Matematik Eğitimi Dergisi, 13(1), 302-327. https://doi.org/10.17522/balikesirnef.511546 